\title{
Native fish community structure and Indo-Pacific lionfish Pterois volitans densities along a depth-temperature gradient in Onslow Bay, North Carolina, USA
}

\author{
Paula E. Whitfield ${ }^{1, *}$, Roldan C. Muñoz ${ }^{2}$, Christine A. Buckel ${ }^{1}$, Brian P. Degan ${ }^{1}$, \\ D. Wilson Freshwater ${ }^{3}$, Jonathan A. Hare ${ }^{4}$
}

${ }^{1}$ Center for Coastal Fisheries and Habitat Research, NCCOS, NOAA, 101 Pivers Island Road, Beaufort, North Carolina 28516, USA

${ }^{2}$ National Marine Fisheries Service, NOAA, 101 Pivers Island Road, Beaufort, North Carolina 28516, USA

${ }^{3}$ Center for Marine Science, University of North Carolina Wilmington, 5600 Marvin K. Moss Road, Wilmington, North Carolina 28409, USA

${ }^{4}$ Narragansett Laboratory, Northeast Fisheries Science Center, National Marine Fisheries Service, NOAA, 28 Tarzwell Drive, Narragansett, Rhode Island 02882, USA

\begin{abstract}
We quantified native fish densities along a depth-temperature gradient within a temperate-tropical marine transition zone (North Carolina continental shelf) to examine the role of depth and temperature in structuring these communities. We also examined the distribution of invasive lionfish (Pterois volitans, P. miles) to evaluate a laboratory-derived thermal minimum for lionfish. We collected year-round continuous bottom water temperature data from 2000 to 2010 and surveyed lionfish (2004 to 2010), conspicuous fishes (2006 to 2010) and cryptic smaller-bodied fishes (2007 to 2010) at depths from 5 to $46 \mathrm{~m}$ using SCUBA. Bottom water temperatures were constant across the depth gradient during summer and increased from inshore to offshore during winter. The conspicuous fish community was structured by 3 depth zones, 5-14, 15-37 and 38-46 $\mathrm{m}$, that corresponded with winter mean temperatures of $13.9,17.9$ and $20.9^{\circ} \mathrm{C}$, respectively. The cryptic fish community was structured by 4 depth zones, $5-15,18-24,27-38.5$ and 39.5-46 $\mathrm{m}$, with corresponding winter mean bottom temperatures of $13.8,15.6,18.7$ and $20.9^{\circ} \mathrm{C}$. In contrast, summer temperatures were not important in structuring either the conspicuous or the cryptic fish community. Thus, fish communities in the spring/summer appear to be structured by the pattern of bottom water temperature experienced the previous winter, supporting previous studies that indicate winter minimum temperature is important for determining fish distribution and abundance in temperate marine ecosystems. In addition, the deeper fish communities were dominated by tropical species. Lionfish, a tropical species, was found in the highest densities from 38 to $46 \mathrm{~m}$ and present in locations with a winter mean of $15.3^{\circ} \mathrm{C}$ and higher. Increasing temperatures could favor a potential expansion of invasive lionfish and native tropical species into the nearshore waters on the North Carolina shelf, resulting in unforeseen community structure and trophic disruptions.
\end{abstract}

KEY WORDS: Lionfish · Pterois volitans · Conspicuous fish · Cryptic fish · Winter mean temperature · Depth $\cdot$ North Carolina $\cdot$ Hard bottom habitat $\cdot$ Climate change

Resale or republication not permitted without written consent of the publisher

\section{INTRODUCTION}

Warming global temperature is linked to spatial shifts in species distributions (Parmesan \& Yohe 2003, IPCC 2007). In recent years, shifts in fish distributions have been documented as generally poleward and changing depths as fishes follow their optimal temperature range (Perry et al. 2005, Nye et al. 2009, Sorte et al. 2010a). The extent of these distribution shifts varies depending on the regional biogeography and species physiology. For example, in the North Sea and northeastern United States, species at the south- 
ern extent of their range exhibited the greatest distribution shifts poleward, while those at the northern boundary shifted poleward and in some cases deeper (Perry et al. 2005, Nye et al. 2009). Fish communities in transition zones off the western coast of Australia and in the northern Gulf of Mexico and the Mediterranean Sea are becoming more tropical (Ben Rais Lasram \& Mouillot 2009, Fodrie et al. 2010, Wernberg et al. 2013). Projections off the eastern coast of Australia and the United States are for warmer winter temperatures to increase overwintering survival of tropical fishes, resulting in range expansions (Figueira \& Booth 2010, Hare et al. 2012b). Thus, marine boundaries that represent zoogeographic transitions (e.g. temperate-tropical) may be important areas to detect evidence consistent with climate change impacts. In warm-temperate locations such as the Carolinian biogeographic province, shifts in distribution may result in changes in fish communities from temperate species to subtropical and tropical species (Parker \& Dixon 1998, Ben Rais Lasram \& Mouillot 2009, Nye et al. 2009, Fodrie et al. 2010), possibly leading to local extirpation of some species and colonization by others (Fodrie et al. 2010, Cheung et al. 2012, 2013).

In the Southeast US Continental Shelf Large Marine Ecosystem (hereafter Southeast US Shelf), Cape Hatteras, North Carolina, represents the northern boundary, where cooler temperate waters originating from the Labrador Current converge with warmer tropical Gulf Stream waters from the south, resulting in a year-round north-south gradient in water temperature. Thus, Cape Hatteras represents both a southern and northern boundary for many temperate and tropical species, respectively. In addition, just south of Cape Hatteras, there is a winterinduced inshore-offshore thermal gradient characterized by colder near-coastal waters and warmer offshore waters that are thermally moderated yearround by the Gulf Stream (Atkinson et al. 1983). This thermal gradient is caused by winter cooling of inshore shallow waters, while offshore the Gulf Stream continues to provide warm water from more southern areas (Atkinson et al. 1983).

The winter inshore-offshore temperature gradient on the Southeast US Shelf is coincident with the shelf depth gradient and likely influences fish community structure year-round. Previous studies in this region found that fish communities shift from temperate to tropical based on depth, with colder winter temperatures usually attributed as the main factor in this shift (i.e. distance from the Gulf Stream) (Miller \& Richards 1980, Grimes et al. 1982, Chester et al. 1984, Sedberry \& Van Dolah 1984). Temperature-linked overwinter survival is an important factor in determining abundance and distribution of marine species along the eastern coast of the United States (Hurst 2007). If ocean warming trends continue as projected (IPCC 2007), the Southeast US Shelf should warm, resulting in an inshore shift in species distributions, analogous to poleward shifts seen elsewhere (Perry et al. 2005, Ben Rais Lasram \& Mouillot 2009, Fodrie et al. 2010). Species-specific differential shifts in distributions could potentially alter interspecific interactions and food webs and have important impacts on fisheries (Nye et al. 2009, Cheung et al. 2012, 2013). However, to date there has not been a quantitative examination of depth and bottom water temperature influence on fish community structure within this region.

Climate change is one of multiple stressors acting on marine ecosystems (Breitburg \& Riedel 2005). The Southeast US Shelf is also under stress from the invasion of the Indo-Pacific lionfish (Pterois volitans, P. miles), and the present overwintering distribution of lionfish extends from Cape Hatteras south to the northern coast of South America (Betancur-R et al. 2011). Lionfish are considered a major threat to Atlantic reefs by reducing reef fish recruitment and biomass and have been implicated in cascading impacts such as decreased coral cover on coral reefs (Albins \& Hixon 2008, Lesser \& Slattery 2011, Green et al. 2012). Water temperature is thought to be one of the few abiotic factors to control lionfish distribution on a large scale. The thermal tolerance of lionfish was established experimentally by Kimball et al. (2004); lionfish perish at $10^{\circ} \mathrm{C}$. Thus, in addition to potential changes in fish community structure, warming temperatures in the Southeast US Shelf should make the area more favorable to lionfish.

Our goal was to document the role of depth and bottom temperature in influencing fish community structure within the Southeast US Shelf near its northern boundary. We examined both summer and winter bottom temperature to evaluate the importance of maximum and minimum temperatures. Baseline community data combined with concomitant collection of key environmental variables are necessary to establish causality between the environment and community change (Parmesan \& Yohe 2003) and for the development of predictive tools to examine the consequences of change (Cheung et al. 2012, 2013, Hare et al. 2012a, Wuenschel et al. 2012). To establish the biological baseline, we surveyed the fish community of larger mobile species along with smaller-bodied cryptic fishes that appear to show increased sensitivity to changes in temperature (Perry et al. 2005). To establish the environmental baseline, 
we deployed temperature sensors at the survey sites and quantified summer and winter bottom temperature, a key variable structuring fish communities in this region and elsewhere (Parker \& Dixon 1998, Kimball et al. 2004, Figueira \& Booth 2010, Wuenschel et al. 2012). We used the temperature data to calculate temperature preference for several of the abundant species in the survey and to evaluate the laboratory-defined thermal tolerance of lionfish.

\section{MATERIALS AND METHODS}

\section{Site characteristics}

Fish surveys were conducted annually from 2004 to 2010 on natural hard bottom reefs (calcium carbonate rock outcroppings), rock jetties and shipwreck sites across the shelf in Onslow Bay, North Carolina, from depths of 5 to $46 \mathrm{~m}$ (see Table S1 in the Supplement at www.int-res.com/articles/suppl/m509p241_supp.pdf). Sites were chosen to represent a gradient of depth and, by proxy, winter bottom water temperature. However, the closeness of the shallower locations to the authors' home port resulted in an uneven distribution of samples across Onslow Bay, North Carolina (Fig. 1). Surveys were conducted annually between April and September based on ship time availability.

Data loggers (HOBO ${ }^{\circledR}$ Water Temp Pro V1 and V2, HOBO ${ }^{\circledR}$ TidBiT v.1) were used to collect bottom water temperatures and were deployed opportunistically at up to 20 locations across the shelf for differing time periods (maximum of $10 \mathrm{yr}$ ) (see Table $\mathrm{S} 2$ in the Supplement). In some cases, temperature loggers were deployed prior to commencement of fish surveys. On reef sites, loggers were attached near the substrate to small moorings with attached subsurface floats, whereas on shipwrecks, loggers were attached directly to the structure. Data loggers recorded 1 observation every $30 \mathrm{~min}$ and were retrieved annually (Fig. 1). Depth at each site was confirmed in situ, but for analyses (below), depths were derived from NOAA chart number 11520.

\section{Bottom water temperature analysis}

To characterize the climatology of Onslow Bay during the 2001 to 2010 time period, we calculated the mean winter and mean summer bottom water temperature for each year and site based on the daily average from the 3 coldest winter months (January, February and March) and the 3 warmest months
(August, September and October), respectively. The relationship between mean winter temperature and depth was examined using linear regression analysis, with temperature as the dependent variable and depth as the independent variable. The relationship between mean summer temperature and depth was examined using non-parametric Spearman correlation, as the data could not be transformed to meet the assumptions of parametric statistics. We also calculated winter bottom temperature at selected depths across the shelf to illustrate the overall trend in bottom temperature throughout the time period of the study.

\section{Fish surveys}

Fish abundance has been estimated within the Southeast US Shelf using hook and line (Grimes et al. 1982, Chester et al. 1984), trawling (Sedberry \& Van Dolah 1984), stationary point counts (Parker \& Dixon 1998) and video surveys (Burge et al. 2012). However, with the exception of stationary point counts and video surveys, these methods do not effectively census smaller benthic-oriented (cryptic) fishes (Willis 2001). To address these deficiencies, we utilized 2 different diver-based underwater visual census (UVC) band transects (Samoilys \& Carlos 2000), hereafter referred to as conspicuous and cryptic fish surveys. Conspicuous fish surveys examined highly mobile conspicuous fish of all sizes (area sampled: $50 \times 10 \mathrm{~m}=$ $500 \mathrm{~m}^{2}$ ) from 2006 to 2010. Cryptic fish surveys (area sampled: $50 \times 2 \mathrm{~m}=100 \mathrm{~m}^{2}$ ) characterized only the smaller-bodied ( $<10 \mathrm{~cm}$ total length) cryptic (or juvenile) fishes (Willis 2001) from 2007 to 2010. For those species observed on both transect types, the adults were generally observed on the conspicuous transects, and the juveniles were generally observed on the cryptic transects. Lionfish were surveyed from 2004 to 2010 using the same method as conspicuous fish, with lionfish-specific surveys occurring 2 yr prior to commencement of community surveys. Our surveys for lionfish and other native fishes were the same and predated recommendations of lionfish-specific survey methods from coral reef habitats (Green 2012). We routinely looked underneath ledge overhangs and within crevices and found that in the hard bottom habitats of Onslow Bay, lionfish were easily visible either on top of the habitat structure, at the base/sand interface of ledges or underneath ledge overhangs. All fish were identified to the lowest taxonomic level (generally species) and assigned a biogeographic designation of temperate, subtropical or tropical based on published sources from FishBase (Froese \& Pauly 2014). 

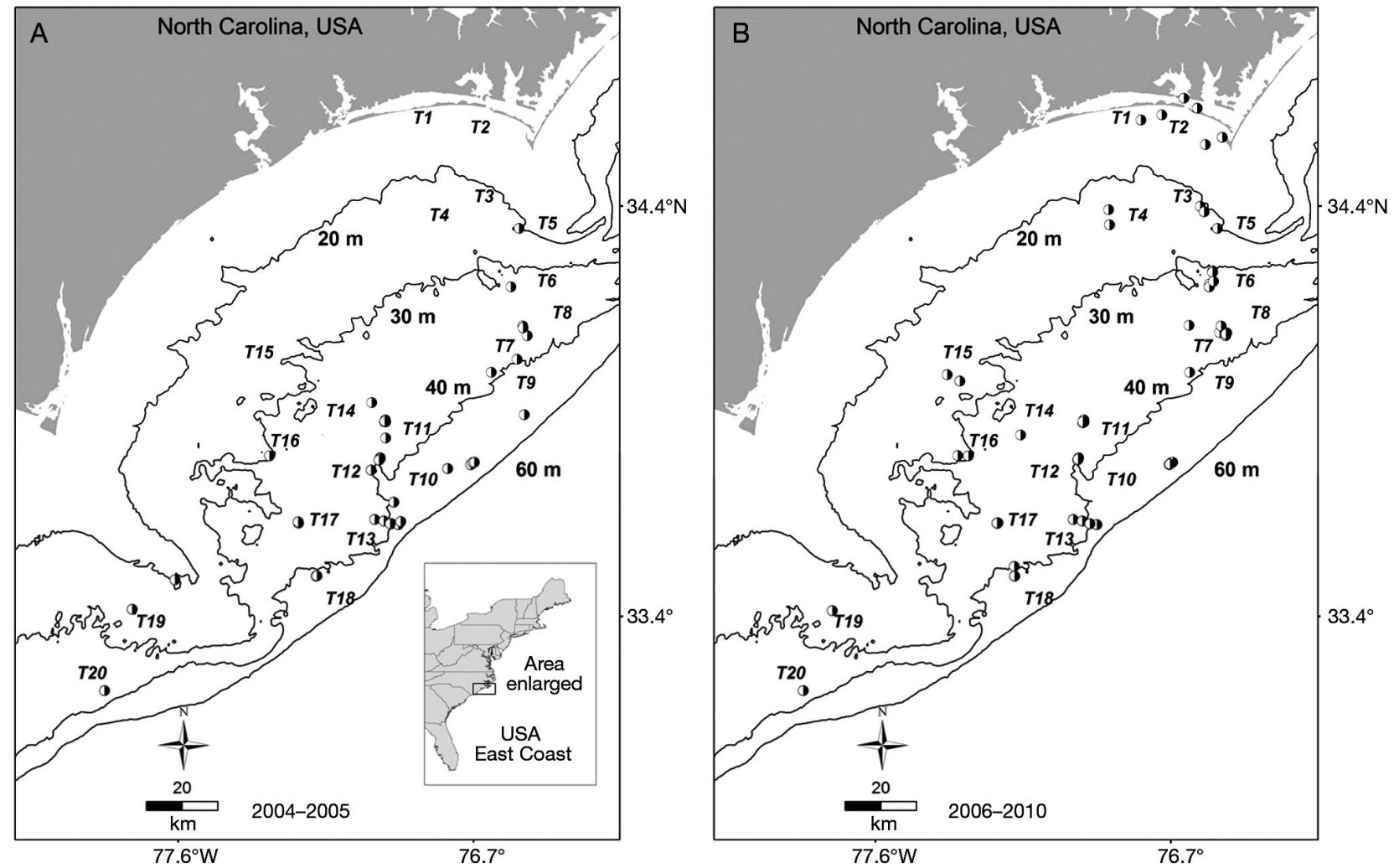

Fig. 1. (A) Lionfish surveys (-) from 2004 to 2005. (B) Lionfish and native conspicuous and cryptic fish surveys from 2006 to 2010 (not all sites surveyed every year). ' $\mathrm{T}$ ' followed by a number indicates general location of each temperature sensor. Details on number of years for each location are shown in Table S2 in the Supplement at www.int-res.com/articles/suppl/ m509p241_supp.pdf

\section{Fish data analysis: relationships to temperature and depth}

\section{Multivariate analyses}

Conspicuous and cryptic fish densities were first square root transformed to reduce the influence of common species, converted into resemblance matrices using Bray-Curtis similarity and visually examined as multi-dimensional scaling plots in PRIMER (Clarke \& Warwick 2001, Clarke \& Gorley 2006). We used the similarity profile (SIMPROF) procedure to determine if there was significant structure within the data to warrant further analysis. The categorical variable year was examined using ANOSIM. The influence of continuous environmental variables (mean summer and winter bottom temperature and depth) on fish community structure was examined using the global BEST and LINKTREE procedures (Clarke et al. 2008). In addition, we added lionfish and predator densities (i.e. groupers) to the global BEST and LINKTREE analyses for the cryptic fish community to examine the potential influence of these factors on cryptic fish community structure. The global BEST procedure determines the combination of environmental variables that 'best' explains fish community structure. Environmental covariates that were found to be collinear (Spearman rank correlation $\rho>0.9$ ) were identified and removed prior to BEST analysis (Clarke et al. 2008). Thus, in the case of conspicuous fish, the environmental data consisted of depth and each temperature variable (analyzed separately), and for cryptic fish, the variables depth, winter and summer temperature, lionfish and predator densities (derived from the conspicuous fish transects) were examined, with depth and the temperature variables alternately removed. Following the methods outlined in Clarke \& Warwick (2001), the environmental data were observed in draftsman plots, transformed (if needed to correct skewness), normalized and converted to resemblance matrices using the Euclidean distance coefficient. Variable(s) in global BEST with the highest Spearman rank correlations with the fish resemblance matrices were explored further in LINKTREE, with the SIMPROF test set at the 0.05 significance level. We further constrained the results so that groups with 
less than 4 sites would not be split further. The LINKTREE procedure is a form of constrained cluster analysis that uses a sequence of SIMPROF tests to identify the specific breaks or 'cutoffs' of the values within the environmental data that best explain the structure within the biotic community (Clarke et al. 2008). SIMPER analysis was conducted to determine the individual species (or taxa) that comprise the different LINKTREE-derived depth zones.

\section{Univariate analyses}

The relationship between Shannon diversity for both conspicuous and cryptic communities and depth and winter temperature was examined using regression analysis, with diversity as the dependent variable and either depth or winter temperature as independent variables. Only winter temperatures were analyzed because multivariate analyses found no effect of summer bottom temperatures on fish community structure. To examine the influence of depth and winter temperature on the tropical composition within the fish assemblage, we calculated a Tropicalization Index (TI) based on the percentage contribution of tropical species to the entire fish community at each site (Wernberg et al. 2013). We conducted regression analyses using the index as the dependent variable and depth as the independent variable. The conspicuous fish data were ranked to meet the assumptions for parametric linear regression analyses.

We also calculated a median temperature of occurrence for many of the conspicuous and cryptic species and examined the temperature distribution of lionfish in more detail. Relatively abundant species were included in this analysis: average density over the whole study period $>100$ ind. ha ${ }^{-1}$ and $>20$ occurrences (conspicuous) and $>15$ occurrences (cryptic). Mean winter temperature and $\log _{10}$-transformed fish abundance were used; data were transformed to reduce the influence of highly abundant observations. Median temperature of occurrence was calculated using a quotient analysis (van der Lingen et al. 2005) as modified by Röckmann et al. (2011). Bootstrapping was used to calculate $95 \%$ confidence intervals for the median temperature of occurrence estimate; specifically, winter temperature and abundance observations were re-sampled with replacement to generate replicate datasets of the same size as the original data set for each species.

Three analyses were conducted to examine lionfish distribution by depth and temperature in more detail. First, lionfish densities were examined by depth zone (from LINKTREE results) and year, using a KruskalWallis 1-way ANOVA on ranks to examine lionfish density differences across year and depth zone. Second, the temperature limit of lionfish (based on mean winter temperature) was estimated using the probability density function of temperature of occurrence. The confidence intervals derived from bootstrapping were used to determine the temperature at which the probability of lionfish abundance exceeds 0 . Third, the relationship between lionfish densities and summer temperatures were examined using linear regression analysis. Lionfish densities were ranked to meet assumptions for parametric statistics.

\section{RESULTS}

\section{Depth and bottom water temperature relationship}

We found a strong linear relationship between depth and winter temperature within Onslow Bay (Fig. 2A, linear regression, temperature ${ }^{\circ} \mathrm{C}=8.892+$ [0.241 $\times$ depth], $\left.\mathrm{R}^{2}=0.72, \mathrm{p}<0.001\right)$. There was no relationship between summer bottom temperature and depth (Spearman rank correlation $\rho=-0.032, \mathrm{p}=$ 0.755), with summer temperature nearly homogeneous across Onslow Bay (Fig. 2B). Winter temperature by year and depth show a consistent pattern by year across the shelf, with shallow areas being the coldest and deeper areas being the warmest, with no interannual trend for increasing temperatures during the time period of this study (Fig. 2C). In fact, there was a consistent decrease across the shelf in winter temperature during the winter of 2008 to 2009. Depth and winter temperature are collinear variables $(\rho>$ $0.9)$; as such, multivariate analyses were conducted separately with winter temperature, summer temperature and depth to avoid statistical problems related to covariance (Clarke et al. 2008).

\section{Fish community analyses}

Multivariate analyses

In 2006 to 2010, 142 taxa from 42 families were observed on the conspicuous fish transects, and in 2007 to 2010, 101 taxa from 28 families were observed on the cryptic fish transects (see Table S3 in the Supplement). We found inherent multivariate structure within the conspicuous and cryptic communities, warranting further multivariate investigation (SIMPROF, conspicuous $\Pi=4.182$, $\mathrm{p}=0.001$; cryptic 

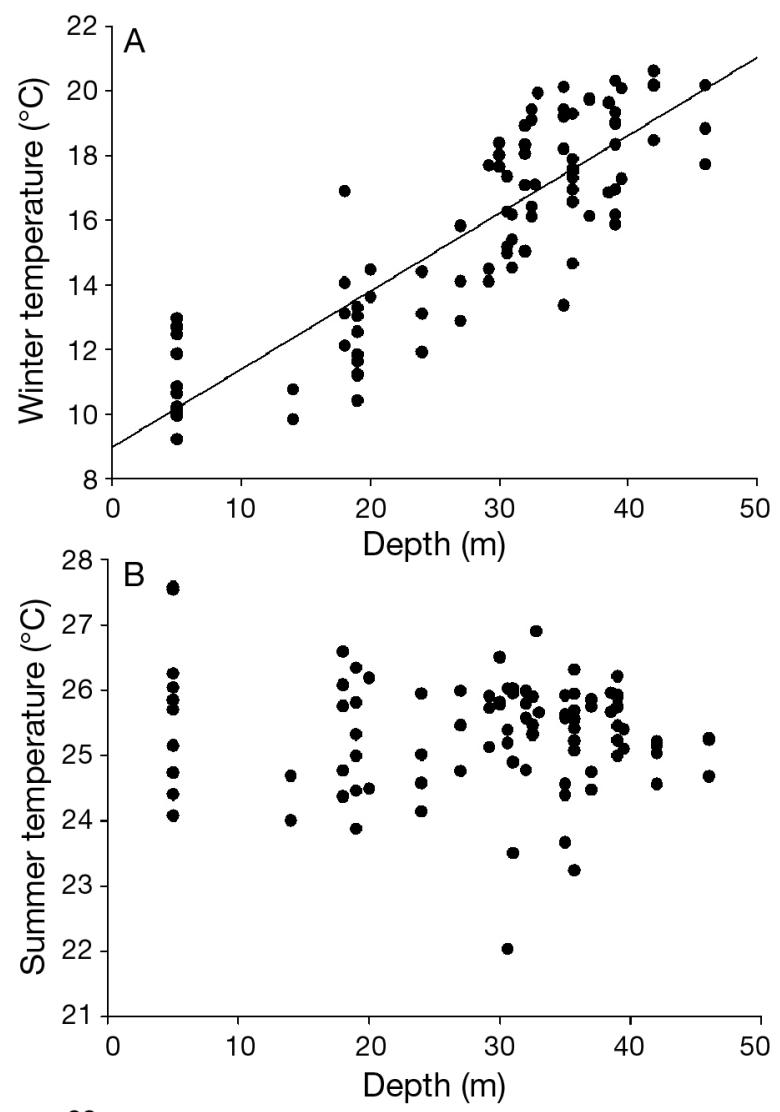

(global BEST depth: conspicuous $\rho=0.687, p=0.001$; cryptic $\rho=0.644, p=0.001$ ) than mean winter temperature (global BEST winter temperature: conspicuous $\rho=0.560, p=0.001$; cryptic $\rho=0.577, p=0.001$ ). Summer temperature was found to be the least important in describing fish community structure (global BEST summer temperature: conspicuous $\rho=$ $0.261, p=0.001$; cryptic $\rho=0.231, p=0.001$ ). Depth structured the conspicuous fish community into 3 main clusters (LINKTREE B > 66\% separation), 5-14, 15-37 and 38-46 m (Fig. 3A), with the greatest separation or difference among groups occurring at depths $<14 \mathrm{~m}$ and $>15 \mathrm{~m}(\mathrm{~B}=85 \%)$. These depth zones corresponded with winter mean temperatures of $13.9,17.9$ and $20.9^{\circ} \mathrm{C}$, respectively. The cryptic community was separated by 4 depth categories (B > $61 \%), 5-15,18-24,27-38.5$ and 39.5-46 m (Fig. 3B), with the greatest community separation ( $\mathrm{B}=84 \%$ ) between depths $<24 \mathrm{~m}$ and $>27 \mathrm{~m}$. These depth zones corresponded to winter mean temperatures of 13.8, 15.6, 18.7 and $20.9{ }^{\circ} \mathrm{C}$, respectively.

Results of the conspicuous fish SIMPER analysis indicated 8 species responsible for $90.7 \%$ of the similarity within 5 to $14 \mathrm{~m}$ (Table 1). The top 5 species responsible for characterizing this depth zone were Diplodus holbrookii, Centropristis striata, Archosargus probatocephalus, Halichoeres bivittatus and Equetus punctatus. Seventeen species comprised $90.9 \%$ of the similarity within 15 to $37 \mathrm{~m}$, and the top 5 species were Haemulon aurolineatum, Haemulon plumieri, C. striata, Mycteroperca microlepis and Mycteroperca phenax. Lionfish were ranked ninth in percent contribution within this depth zone. Twentyfive species comprised $90.2 \%$ of the similarity within 38 to $46 \mathrm{~m}$, with lionfish ranking the highest in percent contribution $(19.4 \%)$ within this depth zone, along with Holocentrus adscensionis, Holacanthus bermudensis, Balistes capriscus and M. phenax in order of decreasing contribution (Table 1).

Winter temperature preference of individual species was consistent with the depth and temperature groupings found in the multivariate analysis (Fig. 4A). Some warm-water species were found in the deep depth zone, and some warm-water and intermediate-temperature species were found in the mid-depth zone. Only cooler-water species were found in the inshore zone. The mean temperature preference of lionfish was $17.7^{\circ} \mathrm{C}_{i}$ the lionfish was one of the warm-water species but was found in both the deep and mid-depth zones.

Similar to conspicuous fish, the number of cryptic fish species representative of the individual depth zones tended to increase with depth across the shelf. better fit for describing fish community structure
$\Pi=3.933, p=0.001)$. There was no difference among years for the conspicuous (ANOSIM R $=0.03, p=$ 0.29 ) or cryptic (ANOSIM $R=0.047 \mathrm{p}=0.09$ ) fish communities; thus, all data were pooled across years for subsequent analyses. Depth provided a slightly 

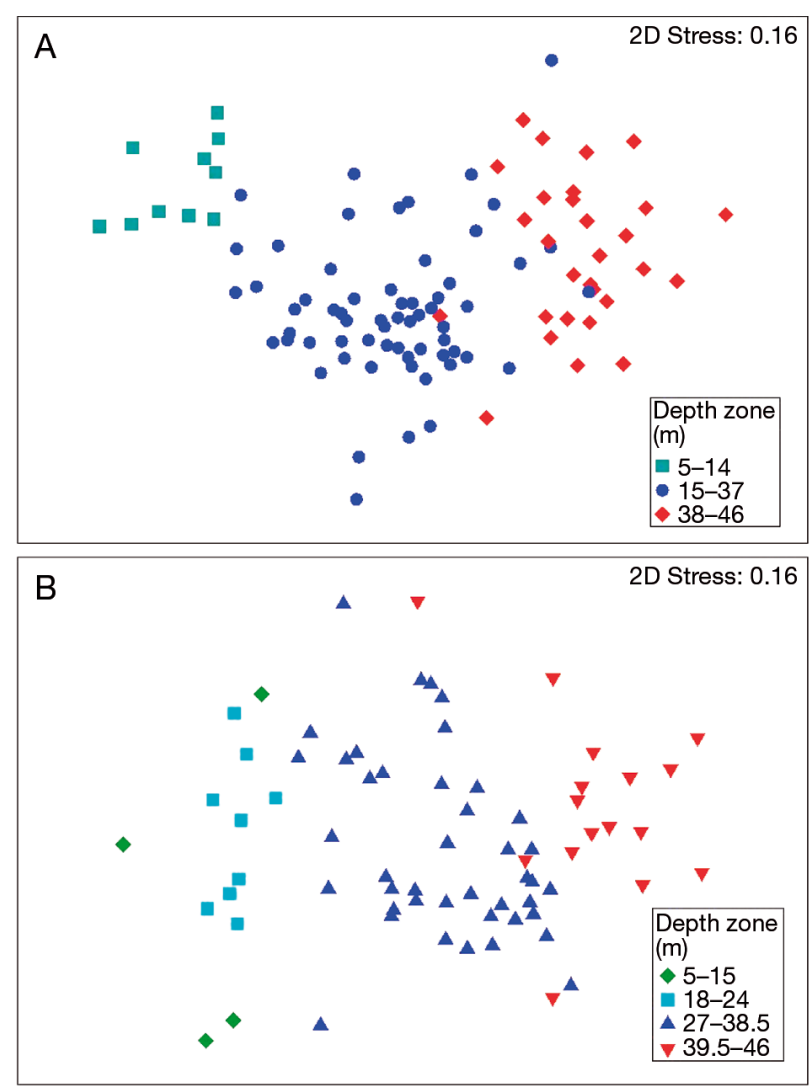

Fig. 3. Multi-dimensional scaling plots color coded by statistically significant depth zone groups based on results from the LINKTREE analysis ( $\mathrm{p}<0.001)$. (A) Conspicuous fish densities, 2006 to 2010. (B) Cryptic fish community structure, 2007 to 2010

Five species accounted for $94.9 \%$ of the similarity within the 5 to $15 \mathrm{~m}$ depth zone (Table 2). In order of decreasing contribution, these species were Serranus subligarius, $H$. bivittatus, D. holbrookii, Chaetodon ocellatus and $H$. plumieri. Seven species comprised $90.2 \%$ of the similarity within 18 to $24 \mathrm{~m}$; the top 5 species were $H$. bivittatus, $S$. subligarius, $H$. aurolineatum, Parablennius marmoreus and Pareques umbrosus. Eleven species comprised $91.4 \%$ of the similarity within 27 to $38.5 \mathrm{~m}$; the top 5 species were Chromis scotti, H. bivittatus, Chromis enchrysurus, $H$. aurolineatum and Thalassoma bifasciatum. Nine species comprised $90.6 \%$ of the similarity within the 39.5 to $46 \mathrm{~m}$ depth zone; the top 5 species were Halichoeres garnoti, C. enchrysurus, Stegastes partitus, T. bifasciatum and C. scotti (Table 2).

Winter temperature preference of individual cryptic species was similar to the results of the conspicuous community and consistent with the depth and temperature groupings found in the multivariate analysis (Fig. 4B). The results of this analysis indicate
Table 1. Dominant species (top $90 \%$ based on SIMPER analysis) from 3 depth zones across the North Carolina continental shelf. Species are listed in descending order of contribution to similarity within each depth zone from 2006 to 2010. Density = mean (+SE). 5-14 m, N = 10; 15-37 m, N = 61; 38-46 m, $\mathrm{N}=30$. (t) = tropical, $(\mathrm{st})=$ subtropical,$(\mathrm{tm})=$ temperate species according to FishBase published sources (Froese \& Pauly 2014). Sim. = average percent similarity, $\mathrm{T}=$ average winter temperature $\left({ }^{\circ} \mathrm{C}\right)$

\begin{tabular}{|c|c|c|}
\hline Species & $\begin{array}{l}\text { Density } \\
\text { (ind. ha }{ }^{-1} \text { ) }\end{array}$ & $\begin{array}{c}\text { Contribution } \\
(\%)\end{array}$ \\
\hline \multicolumn{3}{|c|}{ 5-14 m (Sim. $=35.9, \mathrm{~T}=13.9 \pm 0.02)$} \\
\hline Diplodus holbrookii (st) & $1773.9(970)$ & 31.5 \\
\hline Centropristis striata (tm) & $509.4(286)$ & 20.2 \\
\hline Archosargus probatocephalus (st) & $365.7(172)$ & 13.4 \\
\hline Halichoeres bivittatus (t) & $137.6(52)$ & 7.1 \\
\hline Equetus punctatus (t) & $258.6(216)$ & 5.9 \\
\hline Eucinostomus species (t) & $184.7(113)$ & 5.5 \\
\hline Chaetodipterus faber (st) & $28.3(13)$ & 3.8 \\
\hline Lagodon rhomboides (st) & $85.5(43)$ & 3.2 \\
\hline Cumulative contribution (\%) & & 90.7 \\
\hline \multicolumn{3}{|c|}{$15-37 \mathrm{~m}$ (Sim. $=33.9, \mathrm{~T}=17.9 \pm 0.02)$} \\
\hline Haemulon aurolineatum (st) & $7749.1(1808)$ & 33.4 \\
\hline Haemulon plumieri (st) & $234.2(33)$ & 8.2 \\
\hline Centropristis striata (tm) & $209.7(57)$ & 5.8 \\
\hline Mycteroperca microlepis (st) & $92.2(14)$ & 5.4 \\
\hline Mycteroperca phenax (st) & $83.4(12)$ & 5.2 \\
\hline Pareques umbrosus (st) & $177.7(27)$ & 4.9 \\
\hline Diplodus holbrookii (st) & $718.5(269)$ & 4.3 \\
\hline Holacanthus bermudensis (st) & $48.1(7)$ & 3.3 \\
\hline Pterois volitans $(\mathrm{t})$ & $84.6(15)$ & 3.1 \\
\hline Centropristis ocyurus (st) & $97.3(21)$ & 3.1 \\
\hline Halichoeres bivittatus (t) & $82.5(16)$ & 2.9 \\
\hline Calamus species (st) & $219.3(164)$ & 2.5 \\
\hline Seriola dumerili (st) & $208.8(83)$ & 2.2 \\
\hline Rhomboplites aurorubens (st) & $1931.5(937)$ & 1.9 \\
\hline Chromis scotti (t) & $166.0(48)$ & 1.8 \\
\hline Balistes capriscus (st) & $30.1(6)$ & 1.6 \\
\hline Decapterus species (st) & 2046.9 (899) & 1.6 \\
\hline Cumulative contribution (\%) & & 90.9 \\
\hline \multicolumn{3}{|c|}{$38-46 \mathrm{~m}$ (Sim. $=29.9, \mathrm{~T}=20.9 \pm 0.01$} \\
\hline Pterois volitans $(\mathrm{t})$ & $176.4(24)$ & 19.4 \\
\hline Holocentrus adscensionis (st) & $210.4(131)$ & 8.7 \\
\hline Holacanthus bermudensis (st) & $49.7(8)$ & 7.4 \\
\hline Balistes capriscus (st) & $52.4(11)$ & 5.6 \\
\hline Mycteroperca phenax (st) & $60.4(16)$ & 4.3 \\
\hline Chaetodon sedentarius (st) & $28.3(5)$ & 4.2 \\
\hline Lachnolaimus maximus (st) & $37.7(10)$ & 4.1 \\
\hline Calamus species (st) & $44.0(10)$ & 3.9 \\
\hline Haemulon plumieri (st) & $220.9(94)$ & 3.8 \\
\hline Cephalopholis cruentatus (st) & $36.1(8)$ & 3.2 \\
\hline Priacanthus arenatus (st) & $72.2(23)$ & 3.1 \\
\hline Halichoeres garnoti (t) & $39.0(12)$ & 3.1 \\
\hline Bodianus pulchellus (t) & $35.5(10)$ & 2.4 \\
\hline Seriola dumerili (st) & $48.3(17)$ & 2.3 \\
\hline Malacanthus plumieri (st) & $15.8(4)$ & 2.2 \\
\hline Holacanthus tricolor $(\mathrm{t})$ & $25.1(6)$ & 2.2 \\
\hline Acanthurus coeruleus (t) & $31.5(10)$ & 1.7 \\
\hline Acanthurus bahianus (t) & $51.3(26)$ & 1.5 \\
\hline Pagrus pagrus (st) & $42.0(16)$ & 1.3 \\
\hline Epinephelus morio (st) & $8.8(2)$ & 1.2 \\
\hline Pomacanthus paru (st) & $11.2(3)$ & 1.1 \\
\hline Chaetodon ocellatus (t) & $16.4(5)$ & 1.0 \\
\hline Panulirus argus (t) & $19.1(6)$ & 0.9 \\
\hline Stegastes partitus (t) & $12.1(4)$ & 0.9 \\
\hline Seriola rivoliana (st) & $26.1(11)$ & 0.9 \\
\hline Cumulative contribution (\%) & & 90.2 \\
\hline
\end{tabular}




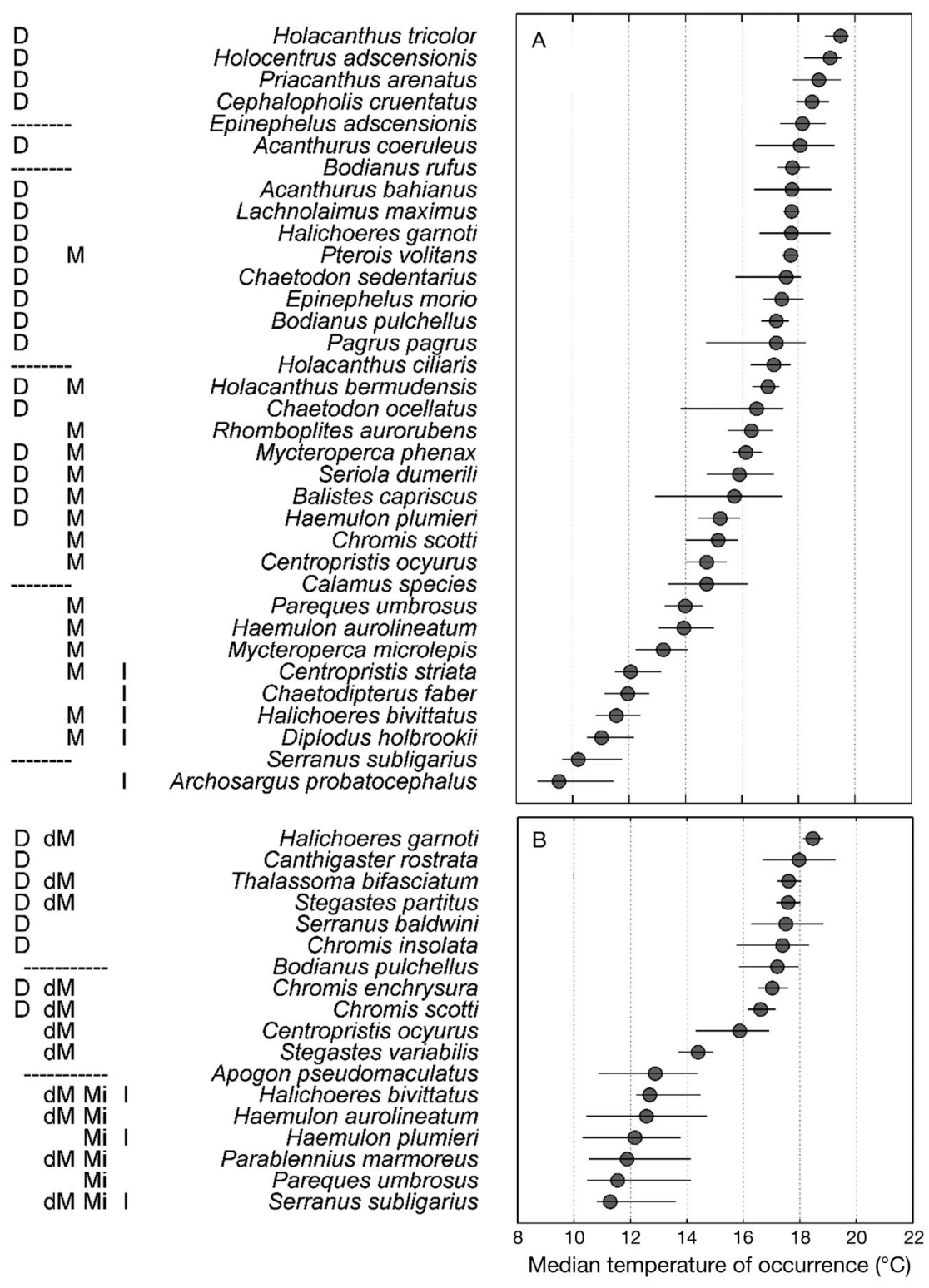

Fig. 4. (A) Median winter temperature preference of conspicuous species. Depth zone designation from the multivariate analyses are provided on the left: I = 5-14 m, M = 15-37 m, D = 38-46 m. Species for which designations were not possible are denoted by -----; these species were not observed frequently enough to use the quotient analysis. (B) Median winter temperature preference of cryptic species. Depth zone designation from the multivariate analyses are provided on the left: $\mathrm{I}=5-15 \mathrm{~m}, \mathrm{Mi}=18-24 \mathrm{~m}, \mathrm{dM}=27-38.5 \mathrm{~m}, \mathrm{D}=39.5-46 \mathrm{~m}$. Error bars: $95 \%$ confidence intervals

2 main groupings, the cooler water species, occurring in shallower water and with a median temperature preference between 11.2 and $13.0^{\circ} \mathrm{C}$, and the warmer-water species, occurring in deeper water with temperatures between 16.0 and $18.3^{\circ} \mathrm{C}$. The temperature preference of Stegastes variabilis occurs between the 2 groups, at a median temperature of occurrence of $14.2^{\circ} \mathrm{C}$.
Univariate analyses

A positive relationship was found between conspicuous fish diversity and depth (linear regression Shannon diversity $=2.025+[0.0166 \times$ depth] $\left.\left[R^{2}=0.25, p<0.001\right]\right)$, but no relationship was found between cryptic fish diversity and depth $\left(R^{2}=0.0022, p=0.7\right)$. For both the conspicuous and cryptic fish communities, a positive relationship was found between the Tropicalization Index (TI) and depth $\left(\mathrm{R}^{2}=\right.$ 0.32, $\mathrm{p}<0.001$, regression: rank $(\mathrm{TI})=4.633+(1.500 \times$ depth $) ; \mathrm{R}^{2}=$ $0.54, \mathrm{p}<0.001$, regression: $\mathrm{TI}=$ $7.808+(1.790 \times$ depth $)$, respectively, Fig. 5). Overall, the cryptic fish community had a higher TI than conspicuous fishes. The TI for cryptic fishes ranged from 12.5 to 100 with an average of 65 , and the index for conspicuous fishes ranged from 4.8 to 60 with an average of 26.8 .

Lionfish were found within the 15 to 37 and 38 to $46 \mathrm{~m}$ depth zones throughout the study, with densities ranging from 0 to 440 ind. $\mathrm{ha}^{-1}$. Overall, lionfish densities increased from 2004 to 2007 then in 2009 decreased back to pre-2006 levels (Fig. 6). This decrease may in part be attributed to colder winter bottom temperatures that occurred during the winter of 2008 to 2009 (Fig. 6). The highest lionfish densities were found in the 38 to $46 \mathrm{~m}$ depth zone. However, there was no significant difference in lionfish densities between depth zones $(15-37$ and $38-46 \mathrm{~m}, \mathrm{p}=$ $0.259)$ or among years $(p=0.113)$. The probability density function indicated that lionfish are absent from areas where mean winter temperature falls below $14^{\circ} \mathrm{C}$ and start to occur at temperatures between 14 and $16^{\circ} \mathrm{C}$ (Fig. 7); site-specific data show that lionfish were only observed in locations with a winter mean temperature of above $15.3^{\circ} \mathrm{C}$ and higher. There was no relationship between lionfish density and summer temperature $(F=0.00204, \mathrm{p}>0.964)$. 
Table 2. Dominant cryptic fish species (top 90\% based on SIMPER analysis) from 4 depth zones across the North Carolina continental shelf. Species are listed in descending order of contribution to similarity within each depth zone from 2007 to 2010. Density = mean (+SE). 5-15 m, $\mathrm{N}=4 ; 18-24 \mathrm{~m}, \mathrm{~N}=10 ; 27-38.5 \mathrm{~m}, \mathrm{~N}=41 ; 39.5-$ $46 \mathrm{~m}, \mathrm{~N}=16$. $(\mathrm{t})=$ tropical, $(\mathrm{st})=$ subtropical,$(\mathrm{tm})=$ temperate species according to FishBase published sources (Froese \& Pauly 2014). Sim. $=$ average percent similarity, $\mathrm{T}=$ average winter temperature $\left({ }^{\circ} \mathrm{C}\right)$

\begin{tabular}{|c|c|c|}
\hline Species & $\begin{array}{l}\text { Density } \\
\text { (ind. ha }{ }^{-1} \text { ) }\end{array}$ & $\begin{array}{c}\text { Contribution } \\
(\%)\end{array}$ \\
\hline \multicolumn{3}{|c|}{ 5-15 m (Sim. = 20.2, T = 13.8 \pm 0.04$)$} \\
\hline Serranus subligarius (st) & $987.5(649)$ & 25.9 \\
\hline Halichoeres bivittatus $(\mathrm{t})$ & 513.4 (209) & 25.2 \\
\hline Diplodus holbrookii (st) & 17034 (13902) & 16.8 \\
\hline Chaetodon ocellatus (t) & $145.2(83)$ & 15.0 \\
\hline Haemulon plumieri (st) & $101.5(45)$ & 11.9 \\
\hline Cumulative contribution (\%) & & 94.9 \\
\hline \multicolumn{3}{|c|}{ 18-24 m $($ Sim. $=42.1, T=15.6 \pm 0.01)$} \\
\hline Halichoeres bivittatus $(\mathrm{t})$ & $2786.2(324)$ & 31.9 \\
\hline Serranus subligarius (st) & $1227.5(134)$ & 22.2 \\
\hline \multicolumn{3}{|l|}{ Haemulon } \\
\hline aurolineatum (st) & $7073.8(2873)$ & 10.7 \\
\hline Parablennius marmoreus (st) & 492.5 (161) & 8.1 \\
\hline Pareques umbrosus (st) & $721.2(310)$ & 8.1 \\
\hline Haemulon plumieri (st) & $1825.0(707)$ & 5.2 \\
\hline Centropristis striata (st) & $245.0(92)$ & 4.1 \\
\hline Cumulative contribution (\%) & & 90.2 \\
\hline \multicolumn{3}{|c|}{ 27-38.5 m (Sim. $=34.4, T=18.7 \pm 0.02)$} \\
\hline Chromis scotti (t) & $4863.8(726)$ & 32.5 \\
\hline Halichoeres bivittatus (t) & $964.0(164)$ & 12.0 \\
\hline Chromis enchrysurus $(\mathrm{t})$ & $1216.0(206)$ & 11.8 \\
\hline Haemulon aurolineatum $(\mathrm{t})$ & $18285.8(6272)$ & 10.5 \\
\hline Thalassoma bifasciatum (t) & $1021.8(208)$ & 8.2 \\
\hline Stegastes partitus $(\mathrm{t})$ & $391.6(102)$ & 5.4 \\
\hline Halichoeres garnoti (t) & $285.6(84)$ & 3.2 \\
\hline Serranus subligarius (st) & $288.3(87)$ & 2.4 \\
\hline Stegastes variabilis $(\mathrm{t})$ & $229.1(65)$ & 2.2 \\
\hline Parablennius marmoreus (st) & $341.6(179)$ & 1.6 \\
\hline Centropristis ocyurus (st) & $208.1(111)$ & 1.5 \\
\hline Cumulative contribution (\%) & & 91.4 \\
\hline \multicolumn{3}{|c|}{ 39.5-46 m (Sim. $=32.1, T=20.9 \pm 0.02)$} \\
\hline Halichoeres garnoti $(\mathrm{t})$ & $880.7(227)$ & 27.0 \\
\hline Chromis enchrysurus (t) & $1961.8(796)$ & 22.5 \\
\hline Stegastes partitus (t) & $305.1(64)$ & 11.7 \\
\hline Thalassoma bifasciatum $(\mathrm{t})$ & $350.6(152)$ & 7.9 \\
\hline Chromis scotti (t) & $2263.8(1590)$ & 6.7 \\
\hline Serranus baldwini $(\mathrm{t})$ & $153.0(44)$ & 5.0 \\
\hline Canthigaster rostrata $(\mathrm{t})$ & $130.3(64)$ & 3.8 \\
\hline Serranus phoebe (st) & $125.4(44)$ & 3.5 \\
\hline Chromis insolatus (t) & $221.4(120)$ & 2.6 \\
\hline Cumulative contribution (\%) & & 90.6 \\
\hline
\end{tabular}

\section{DISCUSSION}

The North Carolina shelf is characterized by a winter temperature gradient of increasing bottom water temperatures that coincides with increasing depth, where the offshore waters are moderated year-round by the presence of the warm Gulf Stream current (Atkinson et al. 1983). This temperature gradient is strongest during the coldest months of the year: Jan-

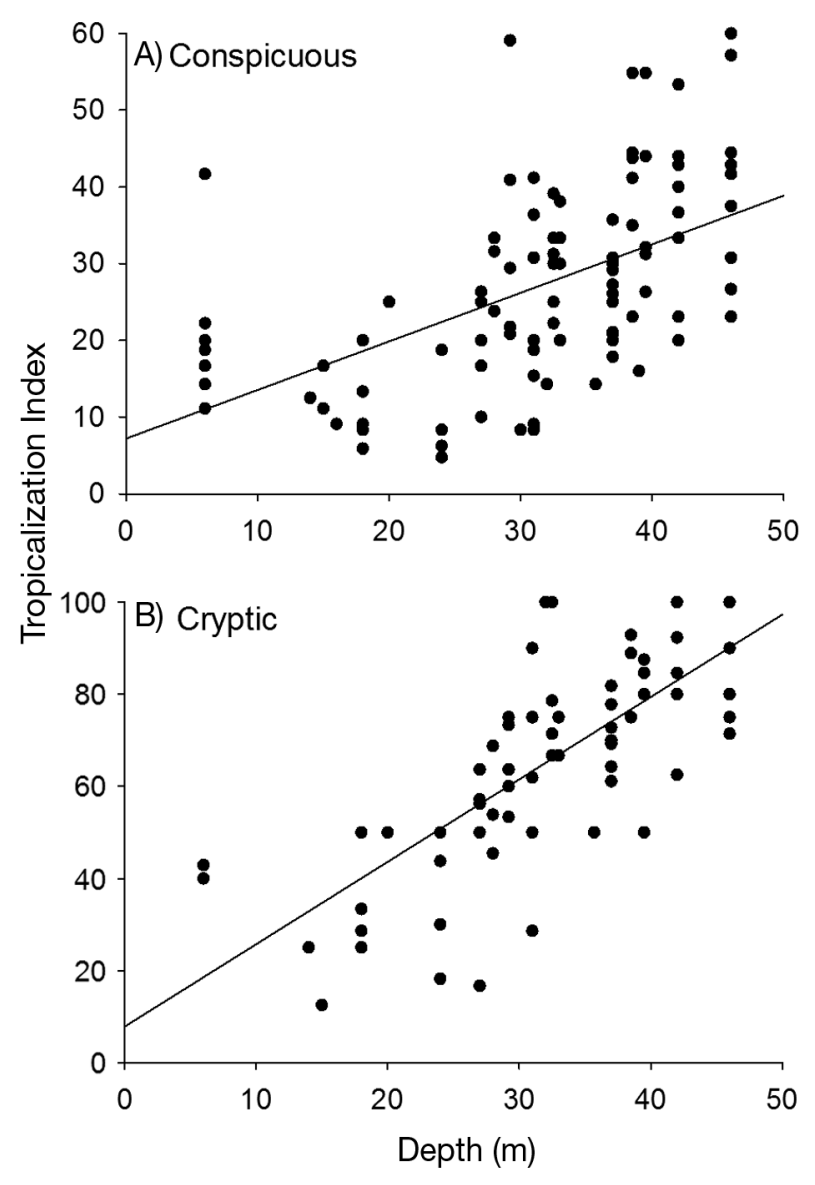

Fig. 5. Tropicalization Index (TI) by depth (m) with resulting linear regression line (see 'Results: Univariate analyses'). (A) Conspicuous species, (B) cryptic species. Note change in $y$-axis scale

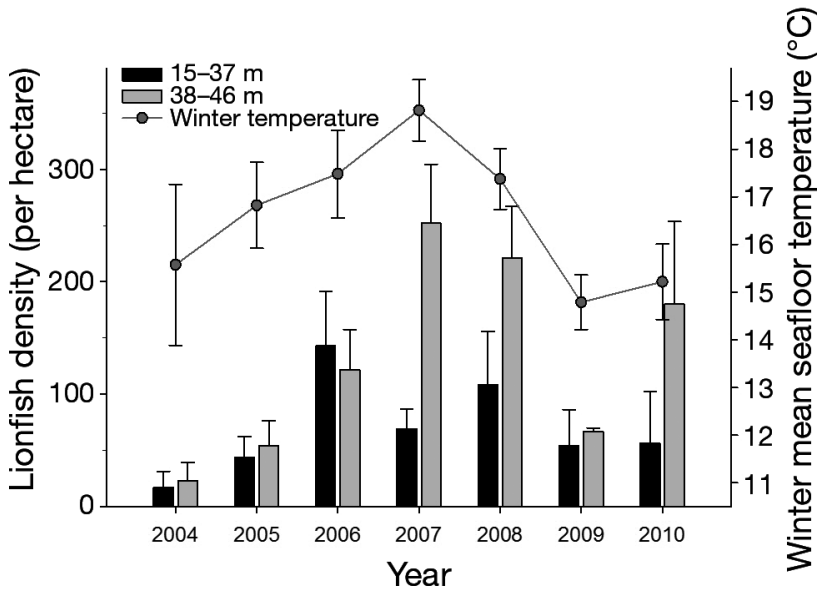

Fig. 6. Lionfish densities in Onslow Bay by year and depth zone with winter mean bottom water temperature overlaid. This mean temperature is an average of the 15-37 and $38-46 \mathrm{~m}$ depth zones; lionfish were never observed within the 5-14 m depth zone during the study. Error bars: SE 


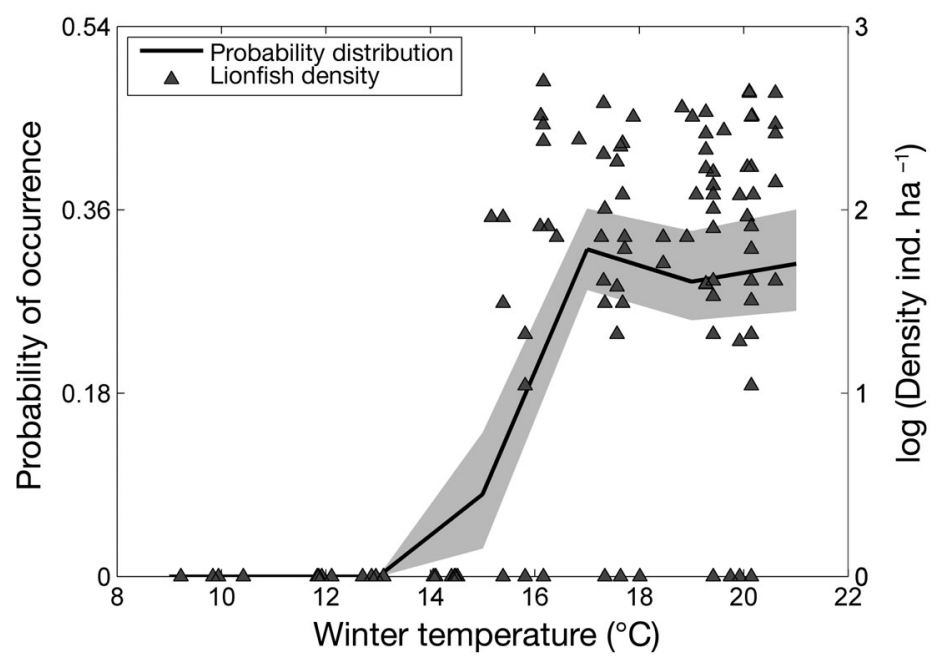

Fig. 7. Probability density of lionfish occurrence as a function of mean winter temperature. The probability density was calculated as a single parameter quotient (see 'Materials and methods: Univariate analyses'). Also shown are lionfish densities as a function of mean winter temperature estimated during the conspicuous fish surveys. Gray area indicates $95 \%$ confidence intervals

uary, February and March. In contrast, during the summer months, the temperature across the shelf is homogeneous. The correlation of winter temperature with depth makes it difficult to distinguish the role of either in structuring fish communities in Onslow Bay. However, evidence of winter temperature as an important factor in structuring these fish communities exists. First, many of the warm-water species observed only in the deepest depth zone are found in shallow waters in more tropical areas (Froese \& Pauly 2014). Second, an increasingly tropical fish community composition with depth and increasing bottom temperatures was found for both the conspicuous and cryptic fish communities. The shift to a more tropical composition with increasing depth has been observed and attributed to warmer winter bottom temperatures in previous studies within the Southeast US Shelf (Miller \& Richards 1980, Grimes et al. 1982, Chester et al. 1984, Sedberry \& Van Dolah 1984). Third, lionfish are found in shallow waters throughout much of the western Atlantic, but off North Carolina, they are restricted to deeper and warmer waters. Since there was no bias toward greater habitat structure (presumably preferred habitat) in the deeper waters (Table S1 in the Supplement), these data suggest that temperature is responsible for the cross-shelf pattern in fish community off North Carolina. However, other biotic and abiotic factors cannot be ruled out. Some of these factors include $\mathrm{pH}$, dissolved oxygen, habitat complexity, predator and prey distributions, and differential recruitment. These factors were not measured in the present study, but our work provides a baseline pattern of community structure that is at least partially explained by winter bottom temperature and depth. These baseline data can now be used to detect future changes to the fish communities such as continued tropicalization (Parker \& Dixon 1998) and species range shifts (Figueira \& Booth 2010), as suggested by Booth et al. (2011).

One of the objectives of this work was to evaluate the laboratory-derived thermal minimum for lionfish in the field. Lionfish perished in the laboratory at $10^{\circ} \mathrm{C}$ (the chronic lethal minimum), regardless of the rate of temperature decline or the acclimation temperature of lionfish (Kimball et al. 2004). This differs from the field-derived minimum thermal threshold of $15.3^{\circ} \mathrm{C}$ (mean winter temperature) found in this study. However, $15.3^{\circ} \mathrm{C}$ is a mean value that represents a threshold for detecting lionfish presence/absence in the field, while $10^{\circ} \mathrm{C}$ is the temperature where lionfish death occurred in the laboratory. Thus, perfect correspondence between the laboratory-derived chronic lethal minimum and the field-derived presence/absence minimum threshold is not expected, and differences between laboratory-derived and observed minimum thresholds have been found in previous studies (Figueira et al. 2009, Figueira \& Booth 2010). Further, Kimball et al. (2004) found that lionfish ceased feeding at $15.3^{\circ} \mathrm{C}$ and became 'stationary and lethargic' at $13^{\circ} \mathrm{C}$, which may increase their susceptibility to predation (Maljkovic et al. 2008). These physiological and behavioral limits appear to have an effect on lionfish distribution within the bounds determined by direct lethal effects of temperature. It is not known whether lionfish move in response to cold winter temperatures or stay and perish (McBride \& Able 1998); juveniles and young adults in an estuary displayed high site fidelity (Jud \& Layman 2012), but Green et al. (2011) examined adult lionfish on patch reefs and showed that movements of at least $130 \mathrm{~m}$ were possible. Whether lionfish move or not, their distribution continues to be limited to the deeper, warmer waters offshore of North Carolina, suggesting that winter bottom temperature is an important mechanism controlling their distribution in the field (Kimball et al. 2004).

The issue of fish movement is relevant to the community analyses conducted here. Depth and winter temperature are important environmental variables. Depth is fixed over the annual cycle, whereas tem- 
perature varies (warm in the summer, cold in the winter). We found a strong relationship between depth, winter temperature and community structure, which was measured during the spring and summer. Either depth is a dominant factor shaping distributions, or winter temperature is dominant, and movement between winter and spring/summer is minimal. Under this latter hypothesis, the distributions observed in the spring/summer reflect the pattern of bottom temperature experienced the winter before. The question of depth or bottom temperature regulation of fish distribution is important (Hare et al. 2012a), and continued research in Onslow Bay could evaluate which factor is most important. As Onslow Bay continues to warm, if temperature is more important, warmer-water species should move into shallower water. If depth is more important, warmer-water species should remain within preferred depth ranges. In addition to these longer-term studies, shorter-term studies could be conducted to examine the scale of annual and seasonal movements of lionfish and other abundant fishes using acoustic telemetry or traditional tagging.

In the future, the greatest rate of community change in the Southeast US Shelf is likely to be in the nearshore waters (Simpson et al. 2011). Range expansions of tropical and subtropical species north of Cape Hatteras are also expected (Hare et al. 2012b), similar to poleward expansions predicted off the eastern coast of Australia (Figueira et al. 2009, Figueira \& Booth 2010). However, it is difficult to predict specific winners and losers with continued warming, but given the high abundance of lionfish and their invasion success within the Atlantic, lionfish are likely to be one of the species to expand their range if winter temperatures become more physiologically hospitable (Sorte et al. 2010a,b). Lionfish have additional value as a potential indicator species for detecting community change in this region for 3 main reasons: (1) they have an established in situ thermal minimum threshold based on mean winter bottom temperature (they are present in temperatures of $15.3^{\circ} \mathrm{C}$ and higher), (2) there are few factors known to limit their distribution on a large scale other than temperature and (3) they are easily recognized. If lionfish become established year-round in areas previously known to be uninhabitable (e.g. habitats $<27 \mathrm{~m}$ depth off North Carolina), then this could indicate that the thermal regime is shifting to favor more tropical species in general. Predicting future range expansions or contractions of other species is more problematic, since thermal tolerance data are not available for most species (but see Figueira \& Booth 2010, Hare et al. 2012b). However, our analyses revealed several tropical species (in addition to lionfish) that are abundant yet restricted to warmer offshore depths in Onslow Bay but have wide depth distributions within the tropics (Tables 1, $2 \& 3$ ). We propose that these fishes (Halichoeres garnoti, Thalassoma bifasciatum, Holacanthus tricolor, Chromis enchrysurus, C. scotti and C. insolatus) (Tables 1 \& 2) may be good candidates as species most likely to expand their distributions shoreward and/or northward (Hare et al. 2012b) under current global warming scenarios (IPCC 2007). Collectively, this group of species could be considered an ecological indicator if (like lionfish) they become established year-round in areas previously uninhabitable (Table 3 ). In addition, the temperature thresholds calculated in this study can now be used to project future fish community distributions based on various carbon emissions projections (Figs. 6 \& 7) (Cheung et al. 2012, 2013, Hare et al. 2012b, Wuenschel et al. 2012).

There is limited evidence that tropicalization of the fish community is already occurring within Onslow Bay, North Carolina (Parker \& Dixon 1998), as it is in the northern Gulf of Mexico (Fodrie et al. 2010), Mediterranean Sea (Ben Rais Lasram \& Mouillot 2009) and western Australian coast (Wernberg et al. 2013). At one location in Onslow Bay ( 29 m depth), Parker \& Dixon (1998) documented 29 new tropical species and increased abundance in 28 other species between the 1970s and early 1990s. In addition, 3

Table 3. List of common tropical fish species, with reportedly wide depth distributions (FishBase, Froese \& Pauly 2014) compared to the truncated depth distributions found in this study off North Carolina (NC). Mean winter temperature ranges are from this study. All species were ranked within the top $\sim 90 \%$ within their respective depth zones based on similarity analyses (Tables 1 \& 2)

\begin{tabular}{|lcrr|}
\hline \multirow{2}{*}{ Species } & \multicolumn{2}{c}{ Depth range $(\mathrm{m})$} & Mean winter \\
\cline { 2 - 3 } & FishBase & $\begin{array}{c}\text { NC, } \\
\text { temperature } \\
\text { this study }\end{array}$ & range $\left({ }^{\circ} \mathrm{C}\right)$ \\
\hline Halichoeres garnoti & $2-80$ & $29.2-46$ & $14.1-20.6$ \\
Thalassoma bifasciatum & $0-40$ & $28-46$ & $16.8-20.6$ \\
Stegastes partitus & $0-100$ & $28-46$ & $15.3-20.6$ \\
Chromis enchrysurus & $5-146$ & $27-46$ & $14.1-20.6$ \\
Chromis insolatus & $20-100$ & $29.2-42$ & $17.6-19.6$ \\
Holacanthus tricolor & $3-92$ & $29.2-42$ & $17.2-20.6$ \\
Chromis scotti & $15-116$ & $27-42$ & $12.9-20.2$ \\
Pterois volitans & $2-55^{\text {a }}$ & $27-46$ & $15.3-20.6$ \\
a Lionfish in its native range; lionfish occur up to 304.8 m in invaded \\
range (R. Gilmore unpubl. data)
\end{tabular}


species (1 subtropical, 2 tropical) observed in this study (cherub fish Centropyge argi, orange back bass Serranus anularis and the greater soapfish Rypticus saponaceous) (see Table S3 in the Supplement) were recently documented as new species to North Carolina by Quattrini et al. (2004). Although it is unclear whether these reports are because of more effective sampling of the cryptic fish communities (i.e. UVC, video) or a northern range expansion, the overall trend toward more tropical composition is expected to continue based on current global carbon emissions projections (IPCC 2007, Cheung et al. 2012). In fact, in our study we found the cryptic fish community to be dominated by tropical species, consistent with the idea that smaller-bodied fishes with short generation times have a demonstrated sensitivity to changing climate conditions (Perry et al. 2005, Bellwood et al. 2006). However, we found that detecting community change using comparisons with previous studies of conspicuous and cryptic fishes within the depths that we examined is problematic because of either the biases associated with the various methods themselves (Connell et al. 1998, Bennett et al. 2009, Burge et al. 2012) or, in the case of cryptic species (Table 2), the lack of previous data. Investigations examining fish community structure in response to changing climatic conditions that do not consider cryptic fishes may fail to detect community shifts if they occur (Bellwood et al. 2006).

Most previous studies in the region used extractive sampling techniques such as angling, which targets larger, economically valuable species (Grimes et al. 1982, Chester et al. 1984), or trawling, which can underestimate larger mobile species and is restricted to low-relief habitat (Sedberry \& Van Dolah 1984). Others used direct observation methods such as stationary point counts using video and divers (Parker \& Dixon 1998, Burge et al. 2012). Fish community differences between extractive sampling and direct observation methods are common (Connell et al. 1998) and have been most recently noted in the North Carolina region by Burge et al. (2012). Burge et al. (2012) used video and diver stationary point counts to survey fishes and summarized differences between the 18 most frequently encountered species in their study and 7 previous studies (Appendix 3, Burge et al. 2012). Because of the variety of sampling methods and the location and scale of the studies, robust conclusions regarding community change are difficult. However, the taxa and general order of importance of species within our study (Table 1) were in broad agreement with the species most important in Burge et al. (2012), and the top-ranking species identified in several previous studies (Grimes et al. 1982, Chester et al. 1984, Sedberry \& Van Dolah 1984) were also represented within the top $90 \%$ of identified fish taxa here (Table 1).

\section{CONCLUSIONS}

Temperate-tropical marine transition zones such as the coastal waters along the North Carolina coast may be areas that will undergo the most ecosystem change as a result of warming ocean temperatures, and previous studies highlighted the importance of these regions as climate change hotspots (Booth et al. 2011). The baseline data collected in this study will assist in detecting climate change impacts, such as the expansion of tropical fish communities into areas previously uninhabited, and will allow the projection of species distribution shifts based on future carbon emissions (IPCC 2007) and the temperature thresholds we report. A diverse assemblage of ecologically and economically valuable fishes can be found on North Carolina temperate reefs, many of which are considered overfished and have suffered population declines in recent years (Rudershausen et al. 2008). If winter temperatures are indeed the overriding factor in structuring these hard bottom reef communities, the continued warming of global temperatures may cause further changes to fish community structure. Increasing temperatures also favor a potential expansion of the invasive lionfish population across the shelf (and northward). These 3 factors combined could further stress native fish communities, potentially leading to unforeseen fish community structure and trophic disruptions as the marine community responds to warmer temperatures (Sorte et al. 2010a), complicating recovery efforts for some species (Nye et al. 2009).

Disclaimer. The scientific results and conclusions, as well as any views or opinions expressed herein, are those of the authors and do not necessarily reflect the views of NOAA or the Department of Commerce.

Acknowledgements. This project spanned $7 \mathrm{yr}$ and was funded by several sources including NOAA's Undersea Research Program, Invasive Species Program and NCCOS and the Center for Fisheries and Habitat Research in Beaufort, North Carolina. We especially thank with great appreciation Doug Kesling (National Undersea Research Center-University of North Carolina Wilmington [NURC-UNCW], Cooperative Institute for Ocean Exploration, Research and Technology [CIOERT]) and the many other technical and safety divers and boat captains that shared their time and energy with us, including Casey Coy, Jay Styron, Joe Hoyt, Jenny Vander Pluym, Jennifer Dorton, Lauren Heesemann, 
Brad Teer, Brett Harrision, Abigail Poray, John Hackney, Shay Viehman, Roger Mays, Brandon Puckett, Jitka Hyniova, Thomas Nassif, Thor Dunmire, Kathryn O' Shaughnessy, Captain Dan Aspenliter, Clem Shemanski, Ken Johns, Lance Horn, Tom Potts and Mike Winfield. We also thank Captain George Purifoy Jr. for deploying and retrieving temperature sensors for many years across Onslow Bay. We also thank Captain Robert Purifoy, Captain Bobby Edwards, Captain Woo Woo Harker and Captain Terrell Gould. We thank Mike Lacroix and Gary Fisher for providing technical assistance and Thomas Nassif for being the best Teacher at Sea ever. The NOAA ship 'Nancy Foster' and her crew is gratefully acknowledged and thanked. Dr. Richard Ehrenkaufer (also known as Dr. Bogus) is also thanked for his generous donation of Bogue Pier water temperature data. We also thank Patti Marraro and Mark Fonseca. The manuscript was improved significantly by reviewers Nate Bachelor, Christina Schobernd, Todd Kellison, Don Field, B. William Gottholm and Alex Chester, as well as 1 anonymous reviewer and Joel Fodrie. Finally, this research would not have been possible without the advanced technical diving programs of CIOERT and the now-defunct NURC-UNCW technical dive training program; we gratefully acknowledge their help in making this research happen.

\section{LITERATURE CITED}

Albins MA, Hixon MA (2008) Invasive Indo-Pacific lionfish Pterois volitans reduce recruitment of Atlantic coral-reef fishes. Mar Ecol Prog Ser 367:233-238

> Atkinson LP, Lee TN, Blanton JO, Chandler WS (1983) Climatology of the southeastern United States continental shelf waters. J Geophys Res 88:4705-4718

Bellwood DR, Hoey AS, Ackerman JL, Depczynski M (2006) Coral bleaching, reef fish community phase shifts and the resilience of coral reefs. Glob Change Biol 12: 1587-1594

> Bennett RH, Goetz A, Sauer WHH, Cowley PD, Palmer RM (2009) Optimisation of underwater visual census and controlled angling methods for monitoring subtidal temperate reef fish communities. Afr J Mar Sci 31:277-287

> Ben Rais Lasram F, Mouillot D (2009) Increasing southern invasion enhances congruence between endemic and exotic Mediterranean fish fauna. Biol Invasions 11: 697-711

> Betancur-R R, Hines A, Acero A, Orti G, Wilbur AE, Freshwater DW (2011) Reconstructing the lionfish invasion: insights into greater Caribbean biogeography. J Biogeogr 38:1281-1293

Booth DJ, Bond N, Macreadie P (2011) Detecting range shifts among Australian fishes in response to climate change. Mar Freshw Res 62:1027-1042

Breitburg DL, Riedel GF (2005) Multiple stressors in marine systems. In: Norse EA, Crowder LB (eds) Marine conservation biology: the science of maintaining the sea's biodiversity. Island Press, Washington, DC, p 167-182

Burge EJ, Atack JD, Andrews C, Binder BM and others (2012) Underwater video monitoring of groupers and the associated hard-bottom reef fish assemblage of North Carolina. Bull Mar Sci 88:15-38

Chester AJ, Huntman GR, Tester PA, Manooch CS III (1984) South Atlantic Bight reef fish communities as represented in hook-and-line catches. Bull Mar Sci 34:267-279

> Cheung WWL, Meeuwig JJ, Feng M, Harvey E and others
(2012) Climate-change induced tropicalisation of marine communities in western Australia. Mar Freshw Res 63: 415-427

> Cheung WWL, Watson R, Pauly D (2013) Signature of ocean warming in global fisheries catch. Nature 497:365-368

Clarke KR, Gorley RN (2006) PRIMER v6: user manual/tutorial. PRIMER-E, Plymouth

Clarke KR, Warwick RM (2001) Change in marine communities: an approach to statistical analysis and interpretation. PRIMER-E, Plymouth

Clarke KR, Somerfield PJ, Gorley RN (2008) Testing of null hypotheses in exploratory community analyses: similarity profiles and biota-environment linkage. J Exp Mar Biol Ecol 366:56-69

Connell SD, Samoilys MA, Smith MPL, Leqata J (1998) Comparisons of abundance of coral-reef fish: catch and effort surveys vs visual census. Aust J Ecol 23:579-586

Figueira WF, Booth DJ (2010) Increasing ocean temperatures allow tropical fishes to survive overwinter in temperate waters. Glob Change Biol 16:506-516

Figueira WF, Biro P, Booth DJ, Valenzuela VC (2009) Performance of tropical fish recruiting to temperate habitats: role of ambient temperature and implications of climate change. Mar Ecol Prog Ser 384:231-239

> Fodrie FJ, Heck KL, Powers SP, Graham WM, Robinson KL (2010) Climate-related, decadal-scale assemblage changes of seagrass-associated fishes in the northern Gulf of Mexico. Glob Change Biol 16:48-59

Froese R, Pauly D (2014) FishBase. www.fishbase.org (accessed 19 May 2014)

Green SJ (2012) Monitoring: an essential action. In: Morris JA Jr (ed) Invasive lionfish: a guide to control and management. Gulf Caribb Fish Inst Spec Publ Ser No. 1, Marathon, FL, p 51-71

Green SJ, Akins JL, Cote IM (2011) Foraging behaviour and prey consumption in the Indo-Pacific lionfish on Bahamian coral reefs. Mar Ecol Prog Ser 433:159-167

> Green SJ, Akins JL, Maljkovic A, Cote IM (2012) Invasive lionfish drive Atlantic coral reef fish declines. PLoS ONE 7:e32596

Grimes CB, Manooch CS, Huntsman GR (1982) Reef and rock outcropping fishes of the outer continental shelf of North Carolina and South Carolina and ecological notes on the red porgy and vermilion snapper. Bull Mar Sci 32: 277-289

> Hare JA, Manderson JP, Nye JA, Alexander MA and others (2012a) Cusk (Brosme brosme) and climate change: assessing the threat to a candidate marine fish species under the US Endangered Species Act. ICES J Mar Sci 69:1753-1768

> Hare JA, Wuenschel MJ, Kimball ME (2012b) Projecting range limits with coupled thermal tolerance-climate change models: an example based on gray snapper (Lutjanus griseus) along the US east coast. PLoS ONE 7 : e52294

> Hurst T (2007) Causes and consequences of winter mortality in fishes. J Fish Biol 71:315-345

IPCC (Intergovernmental Panel on Climate Change) (2007) Summary for policymakers. In: Solomon S, Qin D, Manning $M$ and others (eds) Climate change 2007: the physical science basis. Contribution of Working Group I to the Fourth Assessment Report of the Intergovernmental Panel on Climate Change. Cambridge University Press, Cambridge

Jud ZR, Layman CA (2012) Site fidelity and movement pat- 
terns of invasive lionfish, Pterois spp., in a Florida estuary. J Exp Mar Biol Ecol 414-415:69-74

Kimball ME, Miller JM, Whitfield PE, Hare JA (2004) Thermal tolerance and potential distribution of invasive lionfish (Pterois volitans/miles complex) on the east coast of the United States. Mar Ecol Prog Ser 283:269-278

> Lesser MP, Slattery M (2011) Phase shift to algal dominated communities at mesophotic depths associated with lionfish (Pterois volitans) invasion on a Bahamian coral reef. Biol Invasions 13:1855-1868

Maljkovic A, van Leeuwen TE, Cove SN (2008) Predation on the invasive red lionfish, Pterois volitans (Pisces: Scorpaenidae), by native groupers in the Bahamas. Coral Reefs 27:501

McBride RS, Able KW (1998) Ecology and fate of butterflyfishes, Chaetodon spp., in the temperate, western North Atlantic. Bull Mar Sci 63:401-416

Miller GC, Richards WJ (1980) Reef fish habitat, faunal assemblages, and factors determining distributions in the South Atlantic Bight. Annu Proc Gulf Caribb Fish Inst 32:114-130

> Nye JA, Link JS, Hare JA, Overholtz WJ (2009) Changing spatial distribution of fish stocks in relation to climate and population size on the Northeast United States continental shelf. Mar Ecol Prog Ser 393:111-129

Parker RO, Dixon RL (1998) Changes in a North Carolina reef fish community after 15 years of intense fishing global warming implications. Trans Am Fish Soc 127: 908-920

Parmesan C, Yohe G (2003) A globally coherent fingerprint of climate change impacts across natural systems. Nature 421:37-42

> Perry AL, Low PJ, Ellis JR, Reynolds JD (2005) Climate change and distribution shifts in marine fishes. Science 308:1912-1915

Quattrini AM, Ross SW, Sulak KJ, Necaise AM, Casazza TL, Dennis GD (2004) Marine fishes new to continental United States waters, North Carolina, and the Gulf of Mexico. Southeast Nat 3:155-172

Röckmann C, Dickey-Collas M, Payne MR, van Hal R (2011) Realized habitats of early-stage North Sea herring: look-

Editorial responsibility: Charles Birkeland,

Honolulu, Hawaii, USA ing for signals of environmental change. ICES J Mar Sci 68:537-546

Rudershausen PJ, Williams EH, Buckel JA, Potts JC, Manooch CS III (2008) Comparison of reef fish catch per unit effort and total mortality between the 1970s and 2005-2006 in Onslow Bay, North Carolina. Trans Am Fish Soc 137:1389-1405

Samoilys MA, Carlos G (2000) Determining methods of underwater visual census for estimating the abundance of coral reef fishes. Environ Biol Fishes 57:289-304

Sedberry GR, Van Dolah RF (1984) Demersal fish assemblages associated with hard bottom habitat in the South Atlantic Bight of the USA. Environ Biol Fishes 11: 241-258

Simpson SD, Jennings S, Johnson MP, Blanchard JL, Schon PJ, Sims DW, Genner MJ (2011) Continental shelf-wide response of a fish assemblage to rapid warming of the sea. Curr Biol 21:1565-1570

Sorte CJ, Williams SL, Carlton JT (2010a) Marine range shifts and species introductions: comparative spread rates and community impacts. Glob Ecol Biogeogr 19:303-316

Sorte CJ, Williams SL, Zerebecki RA (2010b) Ocean warming increases threat of invasive species in a marine fouling community. Ecology 91:2198-2204

van der Lingen C, Castro L, Drapeau L, Checkley D Jr (eds) (2005) Report of a GLOBEC-SPACC workshop on characterizing and comparing the spawning habitats of small pelagic fish. GLOBEC Report 21, GLOBEC International Project Office, Plymouth

> Wernberg T, Smale DA, Tuya F, Thomsen MS and others (2013) An extreme climatic event alters marine ecosystem structure in a global biodiversity hotspot. Nat Clim Chang 3:78-82

Willis TJ (2001) Visual census methods underestimate density and diversity of cryptic reef fishes. J Fish Biol 59: 1408-1411

Wuenschel MJ, Hare JA, Kimball ME, Able KW (2012) Evaluating juvenile thermal tolerance as a constraint on adult range of gray snapper (Lutjanus griseus): a combined laboratory, field and modeling approach. J Exp Mar Biol Ecol 436-437:19-27

Submitted: December 13, 2013; Accepted: May 26, 2014

Proofs received from author(s): August 12, 2014 